\title{
An Empirical Analysis for the Effects of Accounting and Auditing Standards and Corporate Governance on Macroeconomic Stability
}

\author{
Makroekonomik İstikrar Üzerinde Muhasebe ve Denetim Standartları ve \\ Kurumsal Yönetimin Etkileri İçin Ampirik Bir Analiz
}

Hülya KESici ÇALIŞKAN ${ }^{1} \odot$, Ayşe ATILGAN SARIDOĞAN² ${ }^{2}$

\begin{abstract}
Macroeconomic stability is important for a country's sustainable economic growth and social welfare. There are many economic and political factors affecting macroeconomic stability at sectoral, national and international levels. In financial system, while investors lend their savings to companies, they decide according to performance indicators of companies in financial statements. However, accuracy and reliability of information in financial statements of companies depends on level of development in accounting and auditing standards on one hand, and on corporate management capacity on other. There is asymmetrical information about accuracy of financial information of firm between company managers and investors who want to invest in company. This asymmetrical information can cause investors to make wrong choices, triggering financial and economic instability. In this context, developments in accounting and auditing standards and corporate governance level play an important role in solving asymmetric information problem and maintaining macroeconomic stability.

In this context, main purpose of this study is to analyse empirically effects of accounting and auditing standards and corporate governance on macroeconomic stability. According to results of study; explanatory variables, Corporate governance and Strength auditing accounting standards affect dependent variable in same direction. The improvement of Accounting and Auditing standards and Corporate Governance climate is important not only for strengthening of firms and sectors, but also for national macroeconomic stability. As a result, giving sufficient importance to development of accounting and auditing standards and corporate governance in economic policy designs will contribute to preservation and strengthening of macroeconomic stability.
\end{abstract}

Keywords: Macroeconomy, Stability, Corporate Governance, Accounting, Auditing

Jel Code: E61, G34, M41

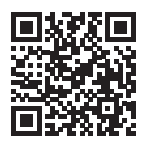

DOI: $10.26650 / J E P R 880830$

'Doç. Dr. İstanbul Üniversitesi, iktisat Fakültesi, Iktisat Bölümü, İstanbul, Türkiye

${ }^{2}$ Dr. Öğr. Üyesi, Canakkale Onsekiz Mart Üni., Çanakkale SBMYO, Muhasebe ve Vergi Bölümü, Çanakkale, Türkiye

ORCID: H.K.C.. 0000-0003-4420-610X; A.A.S. 0000-0001-5160-7687

\section{Corresponding author/Sorumlu yazar:}

Hülya KESiCi ÇALIŞKAN,

İstanbul Üniversitesi, İktisat Fakültesi, İktisat

Bölümü, İstanbul, Türkiye

E-mail/E-posta:

kesici@istanbul.edu.tr

Submitted/Başvuru: 15.02.2021

Revision Requested/Revizyon Talebi:

13.04.2021

Last Revision Received/Son Revizyon:

14.04.2021

Accepted/Kabul: 15.04.2021

Citation/Atıf: Kesici Caliskan, H., \& Atilgan Saridogan, A. (2021). Makroekonomik istikrar üzerinde muhasebe ve denetim standartları ve kurumsal yönetimin etkileri için ampirik bir analiz. Íktisat Politikası Araştırmaları Dergisi Journal of Economic Policy Researches, 8(2), 101-114.

https://doi.org/10.26650/JEPR880830 
öz

Makroekonomik istikrar, bir ülkenin sürdürülebilir ekonomik büyümesi ve sosyal refahı için önemlidir. Sektörel, ulusal ve uluslararası düzeyde makroekonomik istikrarı etkileyen birçok ekonomik ve politik faktör söz konusudur. Finansal sistemde, yatırımcılar, firmalara tasarruflarını borç verirken, firmaların mali tablolardaki performans göstergelerine göre karar vermektedirler. Ancak, firmaların mali tablolarındaki bilgilerin, doğruluğu ve güvenilirliği, bir yandan, muhasebe ve denetim standartlarındaki gelişme düzeyine, diğer yandan ise kurumsal yönetim kapasitesine bağlıdır. Firma yöneticileri ve firmaya yatırım yapmak isteyen yatırımcılar arasında, firmanın mali bilgilerinin doğruluğu ile ilgili olarak, asimetrik bilgi söz konusudur. Bu asimetrik bilgi, yatırımcıların yanlış seçimler yapmasına neden olarak, finansal ve ekonomik istikrarın bozulmasını tetikleyebilir. Bu bağlamda, asimetrik bilgi probleminin çözülmesi ve makroekonomik istikrarın korunmasında, muhasebe ve denetim standartları ve kurumsal yönetim düzeyindeki gelişmeler önemli rol oynamaktadır.

Bu bağlamda, bu çalışmanın temel amacı, muhasebe ve denetim standartları ile kurumsal yönetimin makroekonomik istikrar üzerindeki etkilerini ampirik olarak analiz etmektir. Çalışmanın sonuçlarına göre; açıklayıcı değişkenler, Kurumsal yönetim ile muhasebe ve denetimi standartlarının gelişim düzeyi, bağımlı değişkeni aynı yönde etkilemektedir. Muhasebe ve Denetim standartlarının ve Kurumsal Yönetim ortamının iyileştirilmesi sadece firmaların ve sektörlerin güçlendirilmesi için değil, aynı zamanda ulusal makroekonomik istikrar için de önemlidir. Sonuç olarak, ekonomik politika tasarımlarında muhasebe ve denetim standartlarının ve kurumsal yönetişimin geliştirilmesine yeterince önem verilmesi, makroekonomik istikrarın korunmasına ve güçlendirilmesine katkı sağlayacaktır.

Anahtar kelimeler: Makroekonomi, İstikrar, Kurumsal Yönetim, Muhasebe, Denetim

Jel Code: E61, G34, M41

\section{Introduction}

Macroeconomic stability is important for a country today in terms of sustainable economic growth and social welfare. There are different approaches in the literature for defining and measuring macroeconomic stability. On the other hand, there are many variables that affect macroeconomic stability. The variables affecting macroeconomic stability can be at the level of microeconomics and macroeconomics.

Financial stability is one of the most important factors affecting macroeconomic stability. The deterioration in the financial structure of firms is among the important factors affecting financial instability. In the deterioration of the financial structures of the companies, the defects in the corporate management capacities of the companies and the accounting and auditing standards play an important role. Investors make investment decisions according to the performance indicators in the financial statements of the companies. However, the flaws and manipulations in the accounting and auditing standards negatively affect the reliability of the financial statements. Because the accuracy and reliability of the information in the financial statements reveals an asymmetrical information structure between company managers and investors. This situation causes investors to make wrong decisions under conditions of incomplete and incorrect information. Incorrect decisions in the financial system can lead to the growth of the chain of erroneous decisions in the entire financial system. As a result, the development of corporate governance capacity in companies enables companies to strengthen their financial performance. The level of development in accounting and auditing standards, on the other hand, helps the financial performance of the companies 
to make decisions by internal and external stakeholders in a more accurate and reliable way. If the deterioration in corporate governance level and accounting and auditing standards increase, this may lead to an increase in macroeconomic instabilities.

The main purpose of this study is to analyse empirically the effects of accounting and auditing standards and corporate governance on macroeconomic stability. The data used in the study is from WEF the Global Competitiveness Index dataset for the 141 countries and the year 2019. The method used in the study is the multiple regression analysis with OLS estimator.

Figure 1.1: Macroeconomic Stability, Corporate Governance and Strength Auditing Accounting Standards for the 141 Countries for the Year 2019

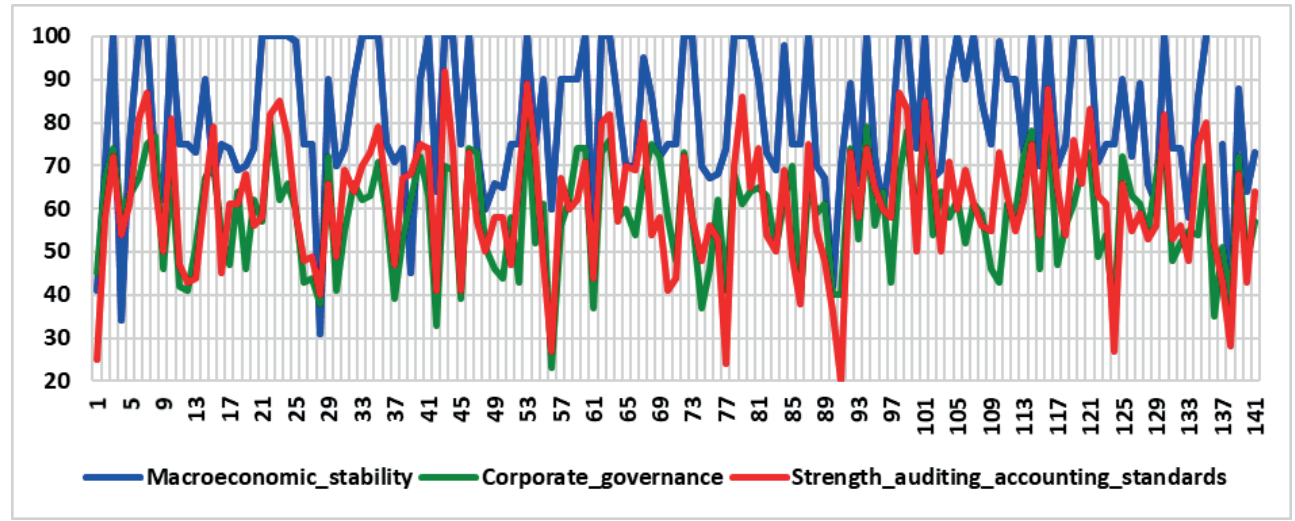

Source: WEF the Global Competitiveness Index dataset, 2019

Figure 1.1. shows graphs for macroeconomic stability, corporate governance and strength auditing accounting standards for the 141 countries and for the year 2019 . When the graphs of the variables are examined, it is observed that there is roughly the same directional relationship between the variables.

The specific aspect of the study, according to the studies in the literature, is that accounting and auditing standards and corporate governance variables are included in the analysis for 141 countries the first time as the explanatory variables that affect macroeconomic stability.

\section{Literature On Macroeconomic Stability, Corporate Governance, Accounting and} Auditing Standards

The main dimensions of macroeconomic stability are price stability, stability of economic activities and employment, and stability of the balance of payments. Price stability means 
that the general level of prices remains at a level that does not harm economic growth and social welfare. Disruption of price stability includes dimensions in which social welfare is negatively affected, such as conditions of hyperinflation of the economy or stagflation. The second fundamental dimension of economic stability is the situation where the economy diverges significantly from the full employment output level. If the economy falls into extreme recession, then the level of unemployment has adverse effects on social and economic well-being. The third dimension of macroeconomic stability is the destabilization of the external balance of the economy. In this case, the economy goes into a balance of payments crisis.

Figure 2.1: Framework for maintaining financial system stability

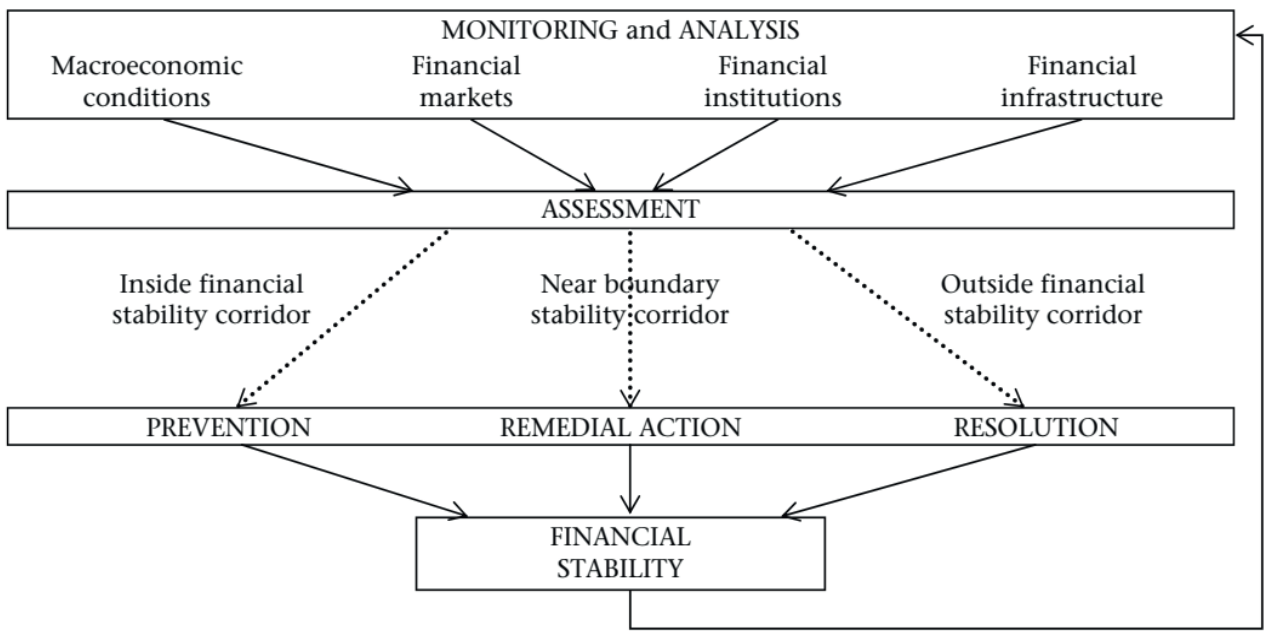

Source: Houben, A., Kakes, J. and G. Schinasi (2004:293) ‘Towards a Framework for Safeguarding Financial Stability’, IMF Working Paper, $04 / 101$

The economy cannot pay its foreign debts, the emerging foreign debt crisis may negatively affect the internal balances of the economy and cause the national economy to be dragged into a crisis (see, Le Fort Varela, Gallardo, \& Bustamante, 2020).

Figure 2.1. shows the framework for maintaining financial system stability. There are many factors affecting financial stability, which are macroeconomic conditions, financial markets, financial institutions and financial infrastructure conditions. 
Figure 2.2: Causal channels of the crisis

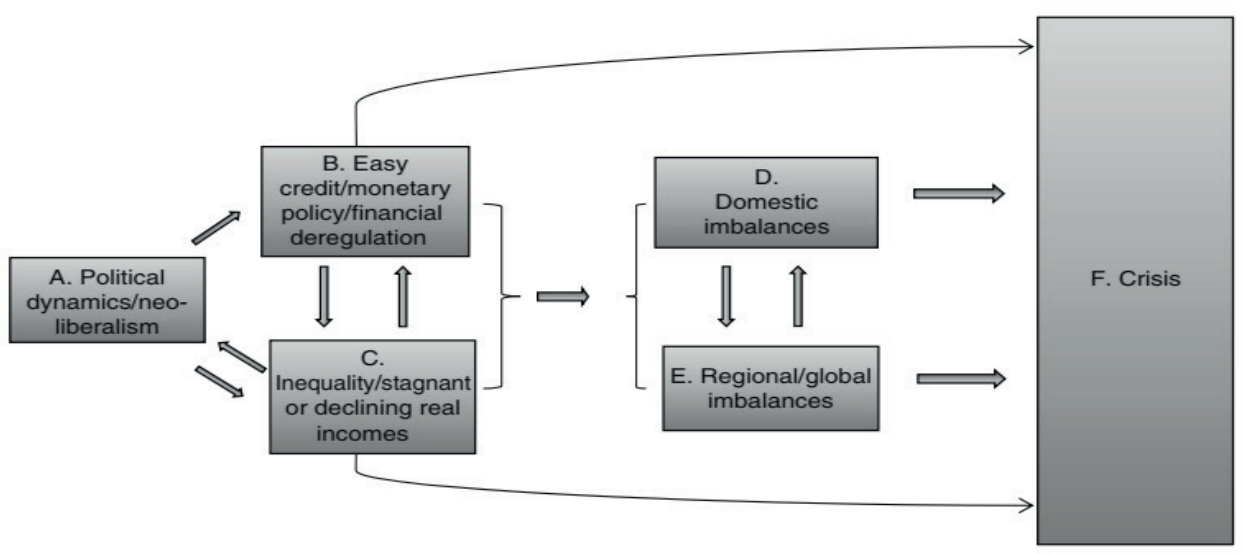

Source: Kucera, D., Galli, R., \& Al-Hussami, F. (2013:290). Keeping up with the Joneses or Keeping One's Head above Water? Inequality and the Post-2007 Crisis. In Beyond Macroeconomic Stability (pp. 288-325). Palgrave Macmillan, London.

Figure 2.2. shows causal channels of the crisis from A to F channels. Political dynamics and neo-liberalism affect easy credit/monetary policy/financial deregulation and inequality/ stagnant or declining real incomes, which affects domestic and regional/global imbalances, which finally results in the economic crisis.

Figure 2.3. shows the natomy of a financial crisis. Mishkin (1992) emphasized that adverse selection and moral hazard problems due to asymmetric information play an important role in the emergence of financial crises (see Figure 2.3.). Mishkin (1992) defines the financial crisis as the loss of the financial markets' function of funding the real sector. In the financial system, while investors lend their savings to companies, they decide according to the performance indicators of the companies in the financial statements. However, the accuracy and reliability of the information in the financial statements of companies depends on the level of development in accounting and auditing standards on the one hand, and on the corporate management capacity on the other. There is asymmetrical information about the accuracy of the financial information of the firm between the company managers and investors who want to invest in the company. This asymmetrical information can cause investors to make wrong choices, triggering financial and economic instability. In this context, developments in accounting and auditing standards and corporate governance level play an important role in solving the asymmetric information problem and maintaining macroeconomic stability. 


\section{Figure 2.3: Anatomy of a financial crisis}

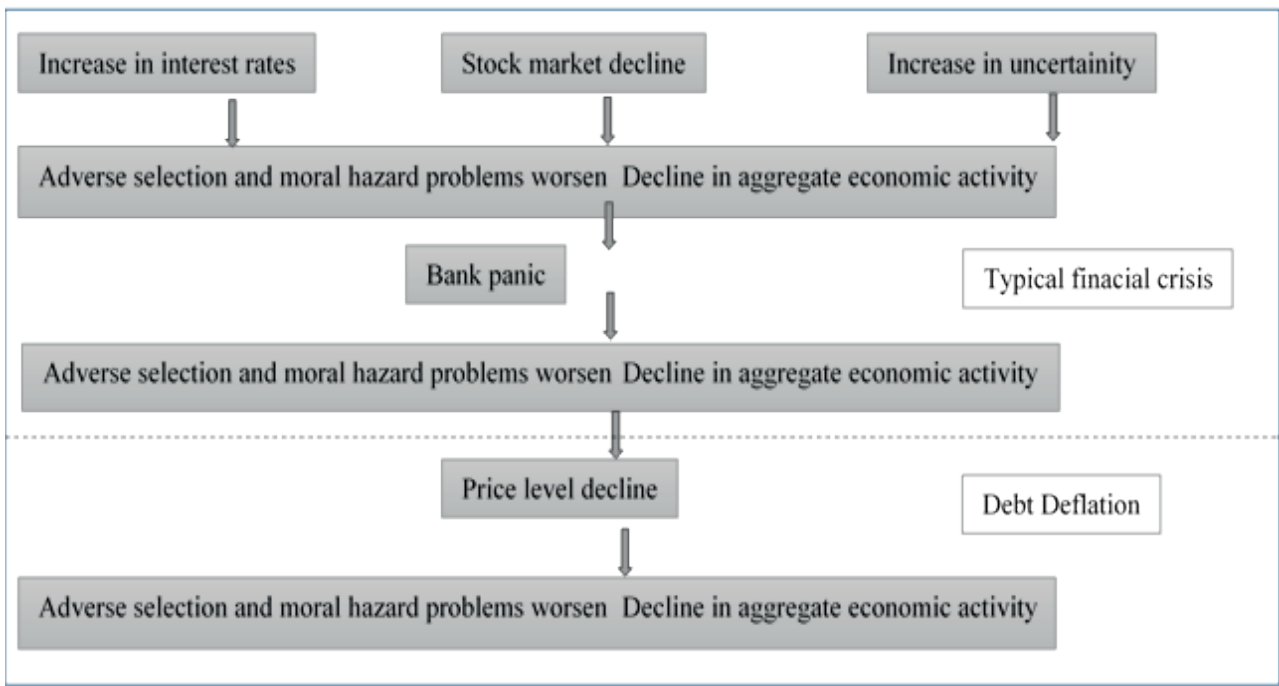

Source: Mishkin, F.S. (1992). Anatomy of financial crisis. Journal of evolutionary Economics, 2(2), 115-130.

Table 2.1: Literature On Factors Affecting Macroeconomic Stability

Authour(s) Scope of the Study Findings

Dornbusch (1980) roles as a macroeconomic

Fischer (1992)

Gali (1994)

Bleaney (1996) instrument.

Discussing exchange rate

Discussing the relationship between economic growth and macroeconomic stability and policies.

Analysing government size on output variability for 22 OECD countries

Testing the relationship between macroeconomic policies and investment, 1980-1990 period.
Although real exchange rate policies have positive effects on the country's competitiveness and full employment output level, it has been determined that they increase instabilities on inflation.

Fischer (1992) stated in his study that there is no simple and quantitative definition of a stable macroeconomic

framework. Conceptually, the components of macroeconomic stability can be considered as low and predictable inflation, proper real interest rates, stable and sustainable fiscal policy, competitive and predictable real exchange rate, and sustainable balance of payments. None of these variables are directly controllable variables, and each of them has different responses to shocks. Among the sources of macroeconomic instability may be the instability of economic policies implemented or instability stemming from external shocks.

It has been determined that there is an inverse and strong relationship between public sector size and GDP growth.

It has been determined that macroeconomic stability has positive effects on the investment climate. 
Table 2.1: Literature On Factors Affecting Macroeconomic Stability

\begin{tabular}{|c|c|c|}
\hline Authour(s) & Scope of the Study & Findings \\
\hline $\begin{array}{l}\text { Clarida, Gali, and } \\
\text { Gertler (2000) }\end{array}$ & $\begin{array}{l}\text { Analysing monetary policy } \\
\text { and macroeconomic stability }\end{array}$ & $\begin{array}{l}\text { It has been determined that the interest rate policy is } \\
\text { effective at the expected inflation and output level. }\end{array}$ \\
\hline $\begin{array}{l}\text { Cecchetti and Krause } \\
\text { (2001) }\end{array}$ & $\begin{array}{l}\text { Analysing financial } \\
\text { structure, macroeconomic } \\
\text { stability and monetary } \\
\text { policy for developed and } \\
\text { developing countries. }\end{array}$ & $\begin{array}{l}\text { It has been determined that the development in the } \\
\text { financial system and banking sector has positive effects } \\
\text { on monetary policy efficiency and macroeconomic } \\
\text { stability. }\end{array}$ \\
\hline $\begin{array}{l}\text { Subramanian, and } \\
\text { Satyanath (2004) }\end{array}$ & $\begin{array}{l}\text { Analysing determinants of } \\
\text { long-run macroeconomic } \\
\text { stability for different regions } \\
\text { and } 1960-2000 \text { period }\end{array}$ & $\begin{array}{l}\text { Democracy has been found to have positive effects on } \\
\text { macroeconomic stability. }\end{array}$ \\
\hline Kaufman (2004) & $\begin{array}{l}\text { Analysing macroeconomic } \\
\text { stability and bank soundness }\end{array}$ & $\begin{array}{l}\text { Positive effects on macroeconomic stability on the } \\
\text { soundness of the banking sector were determined. }\end{array}$ \\
\hline $\begin{array}{l}\text { Gai, Kapadia Millard, } \\
\text { and Perez (2008) }\end{array}$ & $\begin{array}{l}\text { Analysing financial } \\
\text { innovation, macroeconomic } \\
\text { stability and systemic crises }\end{array}$ & $\begin{array}{l}\text { It has been determined that financial innovations have } \\
\text { effects on financial crises. }\end{array}$ \\
\hline Arnold (2009) & $\begin{array}{l}\text { Analysing relationship } \\
\text { between accounting and } \\
\text { current financial crisis }\end{array}$ & $\begin{array}{l}\text { The inability of theorists and accounting theories in } \\
\text { the field of accounting to explain and predict the rise } \\
\text { of financial crises, their inability to question the role } \\
\text { of accounting in these developments, and the lack of } \\
\text { criticism in the accounting field have been accepted as a } \\
\text { deficiency. }\end{array}$ \\
\hline Magnan (2009) & $\begin{array}{l}\text { Analysing relationship } \\
\text { between fair value } \\
\text { accounting and financial } \\
\text { crisis }\end{array}$ & $\begin{array}{l}\text { Finding that fair value accounting had a role in the } \\
\text { growth of the crisis during the } 2007-2009 \text { global } \\
\text { economic crisis. }\end{array}$ \\
\hline Bezemer (2010) & $\begin{array}{l}\text { Analysing relationship } \\
\text { between accounting models } \\
\text { and financial crisis }\end{array}$ & $\begin{array}{l}\text { Finding that macroeconomic models developed based on } \\
\text { accounting are successful in predicting the credit crisis } \\
\text { and economic recession. }\end{array}$ \\
\hline $\begin{array}{l}\text { Kothari and Lester } \\
(2012)\end{array}$ & $\begin{array}{l}\text { Analysing relationship } \\
\text { between role of accounting } \\
\text { and financial crisis }\end{array}$ & $\begin{array}{l}\text { Finding that some US accounting standards contributed to } \\
\text { the } 2008 \text { global economic crisis. }\end{array}$ \\
\hline $\begin{array}{l}\text { Huizinga and Laeven } \\
\text { (2012) }\end{array}$ & $\begin{array}{l}\text { Analysing relationship bank } \\
\text { valuation and accounting } \\
\text { discretion }\end{array}$ & $\begin{array}{l}\text { Finding that the financial statements of banks that did } \\
\text { not comply with the accounting rules during the } 2008 \\
\text { crisis did not provide accurate and reliable information. } \\
\text { They noted that most US banks had book value higher } \\
\text { than market value. Although the inconsistencies between } \\
\text { the market and book values are indicative of future } \\
\text { asset losses, it has been determined that banks make the } \\
\text { necessary adjustments slowly. They found that banks } \\
\text { abused their accounting standards of discretion to hide } \\
\text { their losses and that banks were trying to show their } \\
\text { financial structures better than they were. }\end{array}$ \\
\hline
\end{tabular}


Table 2.1: Literature On Factors Affecting Macroeconomic Stability

\begin{tabular}{lc}
\hline Authour(s) & Scope of the Study \\
\hline $\begin{array}{l}\text { Sutherland and } \\
\text { Hoeller (2012) }\end{array}$ & $\begin{array}{c}\text { Analysing relationship } \\
\text { between debt and } \\
\text { macroeconomic stability for } \\
\text { OECD countries }\end{array}$ \\
& Analysing relationship \\
$\begin{array}{l}\text { Agénor and Pereira } \\
\text { da Silva (2012) }\end{array}$ & $\begin{array}{c}\text { between macroeconomic } \\
\text { stability and monetary } \\
\text { policy }\end{array}$ \\
Sangnier (2013) & $\begin{array}{c}\text { Analysing relationship } \\
\text { between trust and } \\
\text { macroeconomic volatility }\end{array}$
\end{tabular}

Corsetti, Kuester, Meier and Müller

Makri and Papadatos (2014)

Menicucci and Paolucci (2017)

Figlioli, Lemes, and Lima (2017)

Analysing government finances on macroeconomic stability

Analysing the determinants of credit risk in the Greek banking sector

Analysing relationship between Fair Value

Accounting and financial crisis

Analysing relationship among the IFRS, Findings

Finding that indebtedness levels of households, firms and governments have significant effects on macroeconomic instabilities. In addition, it is observed that the higher the indebtedness ratios, the higher the probability of instability.

Finding that monetary policy has positive effects on financial stability.

Finding that there is a similar relationship between trust and macroeconomic stability. It has been found that higher trust level is associated with lower volatility.

Finding that Fiscal discipline and financial stability in the public sector have been found to have positive effects on economic stability.

Finding that the macroeconomic environment and accounting information have a significant impact on the credit risk of the Greek banking system.

Finding that fair value accounting provides useful information when the market is stable, but there may be uncertainties about the reliability and usefulness of fair value accounting during financial fluctuations.

Finding that after the adoption of International Financial Reporting Standards in Brazil, the amount of information synchronicity, and financial crisis in Brazil

Yevdokimov, Melnyk, Lyulyov, Panchenko, and Kubatko (2018)

Arnis, Karamanis, and Kolias (2019)

Bilan, Raišienè, Vasilyeva, Lyulyov, and Pimonenko

Bischof, Laux, and Leuz (2019).

Analysing relationship between economic freedom and macroeconomic stability for $11 \mathrm{EU}$ countries.

Analysing relationship between creative accounting and financial distress

Analysing relationship between public governance efficiency and macroeconomic stability:

Analysing relationship between accounting and financial stability in financial statements increased, but this information was not reflected in the stock prices of companies.

Finding that the positive effect of economic freedom and democracy on macroeconomic stability was determined.

Finding that for the period 2013-014, Greek firms used creative accounting techniques to manipulate financial statements.

Finding that there is a relationship between political and social determinants and macroeconomic stability.

Finding that fair value accounting did not have an important role in the financial crisis of 2008. However, Bischof et al. (2019) noted in their study that there is little evidence on the role of fair value accounting in asset price bubbles. 
Table 2.1: Literature On Factors Affecting Macroeconomic Stability

\begin{tabular}{|c|c|c|}
\hline Authour(s) & Scope of the Study & Findings \\
\hline $\begin{array}{l}\text { Le Fort Varela et al. } \\
(2020)\end{array}$ & $\begin{array}{c}\text { Analysing relationship } \\
\text { between GDP growth and } \\
\text { macroeconomic volatility, } \\
\text { 1984-215 period for } 189 \\
\text { countries }\end{array}$ & $\begin{array}{l}\text { Finding that inflation has negative effects on economic } \\
\text { stability. They also found that different levels of inflation } \\
\text { have negative effects on economic stability at different } \\
\text { levels. On the other hand, they determined that the } \\
\text { volatility in inflation and current account balance had a } \\
\text { negative impact on the volatility of the economy. As a } \\
\text { result, researchers have found that economic instability } \\
\text { negatively affects economic growth and welfare. }\end{array}$ \\
\hline
\end{tabular}

\section{Empricial Analysis}

\subsection{Data}

The data used in the study is from WEF the Global Competitiveness Index dataset for the 141 countries (for full country list see WEF GCI 4.0 2019 Dataset) and the time period covers the year 2019 and yearly data. As explained before, according to the applied studies in the literature, the specific aspect of the study is that accounting and auditing standards and corporate governance variables are included in the analysis as explanatory variables that affect macroeconomic stability for the first time. Variables' definitions are given at Table 3.1.

Table 3.1: Definitions of The Variables Used In The Study

\begin{tabular}{|c|c|}
\hline Variable & Definition \\
\hline Macroeconomic stability & $\begin{array}{l}\text { "The Macroeconomic stability pillar of the Global Competitiveness Index } 4.0 \\
\text { assesses the level of inflation and the sustainability of fiscal policy" The scale } \\
\text { for the score ranges from } 0 \text { to } 100 \text { (best)". }\end{array}$ \\
\hline Corporate Governance & $\begin{array}{l}\text { "Corporate governance index is composed of the indices that are strength } \\
\text { of auditing and accounting standards, conflict of interest regulation and } \\
\text { shareholder governance. The scale for the score ranges from } 0 \text { to } 100 \text { (best)". }\end{array}$ \\
\hline $\begin{array}{l}\text { Strength of auditing and } \\
\text { accounting standards }\end{array}$ & $\begin{array}{l}\text { Response to the survey question "In your country, how strong are financial } \\
\text { auditing and reporting standards?" The scale for the score ranges from } 0 \text { to } \\
100 \text { (best)". }\end{array}$ \\
\hline
\end{tabular}

Source: WEF the Global Competitiveness Index 4.02019 dataset

\subsection{Method}

The method used in the study is the multiple regression analysis with Huber/White/ sandwich estimator to obtain robust errors. The model estimated is given in Equation 1.

$$
Y_{i}=\alpha_{0}+\alpha_{1} X_{1 i}+\alpha_{2} X_{2 i}+\varepsilon_{i} \quad \text { Equation } 1 .
$$

where $i=1,2, \ldots, N$. 


\section{$Y_{i}:$ Macroeconomic stability}

$X_{1 i:}$ Corporate Governance,

$X_{2 i}:$ Strength of auditing and accounting standards

It is expected that the signs of the coefficients belonging to the variables are positive.

$$
\alpha_{1}>0 ; \alpha_{2}>0
$$

\subsection{Empirical Results and Discussion}

Table.3.2. shows the descriptive statistics for the variables. The mean of macroeconomic stability is 80.1 , the mean of corporate governance is 58.7 , the mean of strength auditing accounting standards is 61.2 .

Table.3.2: Descriptive Statistics For the Variables

\begin{tabular}{lccc}
\hline Statistics & $\begin{array}{c}\text { Macroeconomic } \\
\text { stability }\end{array}$ & Corporate governance & $\begin{array}{c}\text { Strength auditing accounting } \\
\text { standards }\end{array}$ \\
\hline Mean & 80.1 & 58.7 & 61.2 \\
Median & 75.0 & 60.0 & 61.0 \\
Variance & 311.3 & 155.5 & 218.2 \\
Std. Deviation & 17.6 & 12.5 & 14.8 \\
Minimum & 0.0 & 23.0 & 20.0 \\
Maximum & 100.0 & 83.0 & 92.0 \\
Range & 100.0 & 60.0 & 72.0 \\
Inter.Range & 30.0 & 19.5 & 21.5 \\
Skewness & -1.0 & -0.3 & -0.3 \\
Kurtosis & 2.4 & -0.6 & 0.0 \\
\hline
\end{tabular}

Table.3.4. shows regression results for the equation 1. Table.3.3. shows Breusch-Pagan / Cook-Weisberg test for heteroscedasticity, indicating heteroscedasticity. For this reason, we estimate the model by using Huber/White/sandwich estimator to eliminate heteroscedasticity.

Table.3.3: Breusch-Pagan / Cook-Weisberg Test For Heteroscedasticity

\begin{tabular}{ll}
\hline$\chi^{2}(1)$ & 7.45 \\
Prob $>$ chi2 & 0.0064 \\
\hline
\end{tabular}

Ho: Constant variance

Variables: fitted values of macroeconomic stability 
According the estimation result in Tablo.3.4., the coefficients of the explanatory variables are statistically significant at the level $0.01,(P>t)$. Null hypotheses for the coefficients ( $H_{0}: \alpha_{1}=0, H_{0}: \alpha_{2}=0, H_{0}: \alpha_{3}=0$ ) are rejected at the $1 \%$ significance level. The F-test result indicates that the model is overall statistically significant at the level 0.01 , $(P>F)$. In the estimated model, there is no problem of multiple linear collinearity $(\mathrm{VIF}<10)$.

Table.3.4: Robust Regression Results for the Equation 1 (Dependent Variable is Macroeconomic stability)

\begin{tabular}{|c|c|c|c|c|c|c|}
\hline & Coef. & Robust Std. Err. & $\mathbf{t}$ & $P>t$ & VIF & 1/VIF \\
\hline Corporate governance & 0.3176159 & 0.0975306 & 3.26 & 0.001 & 2.09 & 0.477359 \\
\hline $\begin{array}{l}\text { Strength auditing } \\
\text { accounting standards }\end{array}$ & 0.5732942 & 0.0947049 & 6.05 & 0.000 & 2.09 & 0.477359 \\
\hline (Constant) & 26.85771 & 5.117374 & 5.25 & 0.000 & & \\
\hline $\mathrm{F}(2,137)=64.68$ & \multicolumn{6}{|c|}{ Number of obs. $=140$} \\
\hline Prob $>F \quad=0.0000$ & \multirow{2}{*}{\multicolumn{6}{|c|}{ Root MSE $=11.552$}} \\
\hline R-squared $=0.5075$ & & & & & & \\
\hline
\end{tabular}

$R 2$ is 0.5075 , and $51 \%$ of the changes in the dependent variable can be explained by the independent variables. The econometric results of the estimated results of the model are summarized below.

$$
\begin{aligned}
& Y_{i}=26.85+0.32 X_{1 i}+0.57 X_{2 i} \\
& \text { R.s.e. }(5.12) \quad(0.10) \\
& \begin{array}{lll}
t & {[5.25] \quad[3.26]} & {[6.05]}
\end{array}
\end{aligned}
$$

The explanatory variables, Corporate governance and Strength auditing accounting standards affect the dependent variable - Macroeconomic stability - in the same direction, results are in line with expectations.

The results obtained in the study are consistent with the literature. It has been determined that corporate governance and accounting and auditing standards have the same effect on macroeconomic stability. There are estimates in the literature that the deliberate or unintentional misapplication of accounting and auditing standards may have effects on the triggering of some financial crises (see, e.g., Arnis et al., 2019; Bischof et al., 2019; Figlioli et al., 2017 ; Menicucci \& Paolucci, 2017; Kothari \& Lester, 2012; Huizinga \& Laeven, 2012; Arnold, 2009). 


\section{Conclusion}

The main purpose of this study is to analyse empirically the effects of accounting and auditing standards and corporate governance on macroeconomic stability. Today, increasing information density makes it difficult for decision makers to make decisions. It is vital for decision makers to produce scientific information, to process and report in accordance with standards. On the other hand, mistakes and manipulations in the production and reporting of information about the financial performance of companies can have negative consequences on decision makers and macroeconomics.

The soundness of the financial sector plays an important role in ensuring macroeconomic stability. For this reason, financial stability is one of the most important factors affecting macroeconomic stability. The deterioration in the financial structure of firms is among the important factors affecting financial instability. In the deterioration of the financial structures of the companies, the defects in the corporate governance capacities and accounting and auditing standards of the companies play an important role. Investors make investment decisions according to the performance indicators in the financial statements of the companies. However, deficiencies and manipulations in accounting and auditing standards adversely affect the reliability of financial statements. Because the accuracy and reliability of the information presented in the financial statements reveals an asymmetrical information structure between company managers and investors. This situation causes investors to make wrong decisions in conditions of incomplete and incorrect information. Incorrect decisions in the financial system can lead to the growth of the chain of erroneous decisions in the entire financial system. As a result, the development of corporate governance capacity in companies allows companies to strengthen their financial performance. The level of development in accounting and auditing standards helps companies make more accurate and reliable decisions by internal and external stakeholders. Increasing deterioration in corporate governance level and accounting and auditing standards may cause macroeconomic instabilities to increase.

According to the empirical results of the study; the explanatory variables, Corporate governance and Strength auditing accounting standards significantly affect the dependent variable in the same direction. The improvement of the Accounting and Auditing standards and the Corporate Governance climate is important not only for the strengthening of firms and sectors, but also for national macroeconomic stability. As a result, giving sufficient importance to the development of accounting and auditing standards and corporate governance in economic policy designs will contribute to the preservation and strengthening of macroeconomic stability. 
Peer-review: Externally peer-reviewed.

Author Contributions: Conception/Design of Study- H.K.Ç., A.A.S.; Data Acquisition- H.K.Ç., A.A.S.; Data Analysis/Interpretation- H.K.Ç., A.A.S.; Drafting Manuscript- H.K.Ç., A.A.S.; Critical Revision of ManuscriptH.K.Ç., A.A.S.; Final Approval and Accountability- H.K.Ç., A.A.S.; Material and Technical Support- H.K.Ç., A.A.S.; Supervision- H.K.Ç., A.A.S.

Conflict of Interest: The authors have no conflict of interest to declare.

Grant Support: The authors declared that this study has received no financial support.

\section{References}

Agénor, P. R., \& Pereira da Silva, L. A. (2012). Macroeconomic stability, financial stability, and monetary policy rules. International Finance, 15(2), 205-224.

Arnis, N., Karamanis, K., \& Kolias, G. (2019). Detecting creative accounting in businesses in financial distress. Accounting and Finance Research, 8(2), 232.

Arnold, P. J. (2009). Global financial crisis: The challenge to accounting research. Accounting, organizations and Society, 34(6-7), 803-809.

Bezemer, D. J. (2010). Understanding financial crisis through accounting models. Accounting, organizations and society, 35(7), 676-688.

Bilan, Y., Raišienè, A. G., Vasilyeva, T., Lyulyov, O., \& Pimonenko, T. (2019). Public Governance efficiency and macroeconomic stability: Examining convergence of social and political determinants. Public Policy and Administration, 18(2), 241-255.

Bischof, J., Laux, C., \& Leuz, C. (2019). Accounting for financial stability: Lessons from the financial crisis and future challenges. CFS Working Paper, No. 622

Bleaney, M. F. (1996). Macroeconomic stability, investment and growth in developing countries. Journal of development economics, 48(2), 461-477.

Cecchetti, S. G., \& Krause, S. (2001). Financial structure, macroeconomic stability and monetary policy (No. w8354). National Bureau of Economic Research.

Clarida, R., Gali, J., \& Gertler, M. (2000). Monetary policy rules and macroeconomic stability: evidence and some theory. The Quarterly journal of economics, 115(1), 147-180.

Corsetti, G., Kuester, K., Meier, A., \& Müller, G. J. (2013). Sovereign risk, fiscal policy, and macroeconomic stability. The Economic Journal, 123(566), F99-F132.

Dornbusch, R. (1980). Exchange rate rules and macroeconomic stability. NBER Working Paper, (w0473).

Figlioli, B., Lemes, S., \& Lima, F. G. (2017). IFRS, synchronicity, and financial crisis: the dynamics of accounting information for the Brazilian capital market. Revista Contabilidade \& Finanças, 28(75), 326-343.

Fischer, S. (1992). Macroeconomic stability and growth. Cuadernos de Economía, 29(87), 171-186.

Gai, P., Kapadia, S., Millard, S., \& Perez, A. (2008). Financial innovation, macroeconomic stability and systemic crises. The Economic Journal, 118(527), 401-426.

Gali, J. (1994). Government size and macroeconomic stability. European Economic Review, 38(1), 117-132.

Houben, A., Kakes, J. \& Schinasi, G. (2004). Towards a framework for safeguarding financial stability. IMF Working Paper, 04/101.

Huizinga, H., \& Laeven, L. (2012). Bank valuation and accounting discretion during a financial crisis. Journal of Financial Economics, 106(3), 614-634. 
Kaufman, G. G. (2004). Macroeconomic Stability, Bank Soundness, and Designing Optimum Regulatory Structures. Multinational Finance Journal, 8(3/4), 141-171.

Kothari, S. P., \& Lester, R. (2012). The role of accounting in the financial crisis: Lessons for the future. Accounting Horizons, 26(2), 335-351.

Kucera, D., Galli, R., \& Al-Hussami, F. (2013:290). Keeping up with the Joneses or Keeping One's Head above Water? Inequality and the Post-2007 Crisis. In Beyond Macroeconomic Stability (pp. 288-325). Palgrave Macmillan, London.

Le Fort Varela, G., Gallardo, B., \& Bustamante, F. (2020). Macroeconomic stability and economic growth: myths and realities. CEPAL Review.

Magnan, M. L. (2009). Fair value accounting and the financial crisis: messenger or contributor?. Accounting perspectives, 8(3), 189-213.

Makri, V., \& Papadatos, K. (2014). How accounting information and macroeconomic environment determine credit risk? Evidence from Greece. International Journal of Economic Sciences and Applied Research, 7(1).

Menicucci, E., \& Paolucci, G. (2017). Fair Value Accounting within a Financial Crisis: An Examination of Implications and Perspectives. International Journal of Business and Social Science, 8(2), 41-56.

Mishkin, F. S. (1992). Anatomy of a financial crisis. Journal of evolutionary Economics, 2(2), 115-130.

Sangnier, M. (2013). Does trust favor macroeconomic stability?. Journal of Comparative Economics, 41(3), 653668.

Subramanian, A., \& Satyanath, S. (2004). What determines long-run macroeconomic stability? Democratic institutions. IMF Working Paper No. 04/215

Sutherland, D., \& Hoeller, P. (2012). Debt and macroeconomic stability: An overview of the literature and some empirics. OECD Economic Department Working Papers, (1006), 0_1.

World Economic Forum Global Competitiveness Index, 2019

Yevdokimov, Y., Melnyk, L., Lyulyov, O., Panchenko, O., \& Kubatko, V. (2018). Economic freedom and democracy: Determinant factors in increasing macroeconomic stability. Problems and Perspectives in Management, 16(2), 279-290. 